Article

\title{
Financial Knowledge's Role in Portuguese Energy Literacy
}

\author{
Ana Martins, Mara Madaleno ${ }^{D}$ and Marta Ferreira Dias* \\ Research Unit on Governance, Competitiveness and Public Policies (GOVCOPP), Department of Economics, \\ Management, Industrial Engineering and Tourism (DEGEIT), University of Aveiro, \\ Campus Universitário de Santiago, 3810-193 Aveiro, Portugal; anapmartins@ua.pt (A.M.); \\ maramadaleno@ua.pt (M.M.) \\ * Correspondence: mfdias@ua.pt; Tel.: +351-234-370-361
}

Received: 30 May 2020; Accepted: 29 June 2020; Published: 2 July 2020

\begin{abstract}
Energy literacy is a concept which is not widely known by the public; however, it has captured the attention of several researchers in recent years. Concerning the assessment of energy and financial knowledge and people's attitudes, intentions and behavior, it provides a global view of people's knowledge, feelings, concerns and habits related to energy usage. Since energy is such an important resource in our daily lives, we can hardly imagine living without it. Moreover, considering that its production often requires the use of limited resources and leads to the worsening of already existing environmental problems, finding ways to alert consumers to the efficient management of their consumption is an urgent need. Therefore, in this article, we aimed to evaluate energy literacy levels, considering all the dimensions mentioned above, and search for the determinants of these levels. As an added novelty, we also aimed to determine the role of financial knowledge on energy literacy dimensions. After distributing a questionnaire to the university community in Portugal, we found good levels of energy literacy, despite moderate levels of energy and financial knowledge. Gender seems to be a determinant of all energy literacy dimensions, and financial knowledge has a positive and significant impact on energy knowledge.
\end{abstract}

Keywords: energy-related knowledge; financial knowledge; attitude; behavior; Portuguese energy literacy

\section{Introduction}

The challenge of climate change and the scarcity of fossil fuels have created an urgent need to seek effective ways to minimize the consequences of these problems. One of the most effective approaches to answering these challenges-and one that may be widely applied, as all citizens may contribute to its development-is to reduce/manage energy consumption. However, this reduction in consumption implies changing behaviors and habits of daily life and making the most appropriate energy-related choices. For this to be possible, citizens first need to have some basic knowledge about energy, namely how it is produced, distributed and used, what is its cost, how much energy is consumed by a piece of particular equipment and which are the ways to save energy. Secondly, they must also have financial knowledge-at least, sufficient knowledge to perform financial calculations and to evaluate investments, as well as knowing the price of electricity. These two types of knowledge are expected to provide citizens with the necessary skills and motivation to determine the necessary changes to achieve efficient behavior.

However, most studies show that while the population has a good knowledge of energy, this knowledge is not translated into a strong motivation that may lead to changes in behavior. The low levels of financial knowledge and the lack of attention to electricity expenditure contribute 
significantly to the low awareness and concern regarding energy issues and often lead to inefficient choices regarding electrical equipment and higher electricity consumption [1]. Thus, in addition to the importance of assessing energy and financial knowledge levels, it is also urgent to understand which factors make it easier and/or harder to translate this knowledge into the correct energy decisions.

Using a sample of members of Portuguese universities, including students, teachers, researchers and technicians, we aimed to measure literacy levels in its three dimensions-knowledge (energy and financial), attitude and behavior - and verify which factors influence those dimensions. Finally, we seek to explore the role of financial knowledge on energy literacy.

This article's contributions are twofold. First, to the best of our knowledge, this is the first study that assesses the energy literacy of a university community in its three dimensions, considering that knowledge encompasses not only issues related to energy but also the mastery of certain financial concepts. Second, this is also the first study to investigate the role of financial knowledge on energy literacy in Portugal. The results show that the Portuguese university community has good levels of energy literacy, achieved thanks to good performance both in terms of attitude and behavior. However, there seems to be a gap in knowledge.

The article is organized into the following six sections. In the next section, we present the literature review; in Section 3, we describe the methodology and data; in Section 4, we present the results; in Section 5, we discuss the results; and in Section 6, we summarize the main conclusions, suggest some policy recommendations, and present some suggestions for future work.

\section{Literature Review}

In recent years, several research studies have been conducted on energy literacy. Although there is not yet consensus regarding its definition there is still no commonly accepted scale for measuring energy literacy, several works have used their own scales or have followed the guidelines suggested in specific articles. According to the U.S. Department of Energy [2] (p. 4), energy literacy may be defined as follows:

"... an understanding of the nature and role of energy in the universe and in our lives. Energy literacy is also the ability to apply this understanding to answer questions and solve problems."

Citizens with moderate energy literacy can identify energy movements, understand how much energy they use, understand the purpose of the energy they use and how it is produced, assess relevant and reliable information about energy, use energy in a sustainable form, consider the environmental impacts and consequences of its use, make informed decisions and continue to learn about energy throughout their life. For all these skills to be included, it is necessary to understand what energy is and how it is produced, as well as to be able to answer some basic questions regarding energy and be aware that energy production and consumption affect the environment, among other issues. Considering this, all consumers should try to consume as efficiently as possible, and finally, apply their knowledge and awareness to their day-to-day decisions and actions. Considering these facts, Dewaters and Powers [3] argue that the assessment of energy literacy levels may be divided into the assessment of three main components: knowledge, attitude and behavior. However, the more recent literature has gone even further, highlighting the role of financial knowledge in making sustainable and efficient decisions, as mentioned earlier in Martins et al. [4].

The levels of energy literacy in most countries reported by the literature are low, mainly due to the results regarding behavior [5-7]. Although people demonstrate moderate levels of knowledge and even positive attitudes concerning energy savings, these do not seem to be translated into more sustainable behavior [8-14]. In fact, according to Danner et al. [15], the behavior is largely influenced by habits. Most of our actions of energy consumption are derived by "lock-in" practices; that is, by habits which are replicated almost automatically, with low levels of deliberation or thinking [16].

Kumar [17] and Filippini et al. [18] measured a similar concept-energy-related financial literacy—and also obtained low levels of literacy for Nepal and Switzerland, respectively. More than 
two-thirds of consumers were shown not to calculate returns from investments, preferring to use shortcuts rather than optimizing their spending, which supports the view that consumers have limited rationality [19]. This limited rationality is further enhanced by the fact that most consumers are unaware of their electricity costs, which makes it difficult for them to realize the monetary value they could save by using more efficient equipment, for example. This may be seen from the study by Filippini et al. [19], in which the authors found that $45.6 \%$ of Swiss people who reported that they knew the price of $1 \mathrm{kWh}$ of electricity also reported not knowing the exact value of their electricity expenses, and the study by Kumar [17], in which $40 \%$ of participants said that they do not know the value of their annual electricity expenses. This lack of knowledge and attention to the price of electricity leads to results, as observed by Kumar [17], in which one in four participants never thought of replacing their equipment over 10 or more years. These difficulties may also make the decision between two similar pieces of electrical equipment more difficult because it may prevent the correct resolution of the optimization problem inherent to the choice. Solving this problem involves knowledge of the equipment purchase prices, the electricity consumed by each piece of equipment, the expected frequency or intensity of its use, its useful life and the current price of electricity [19].

There are also several factors capable of influencing energy literacy levels. These factors may be divided into two categories: personal characteristics (gender, age, education, etc.) and social resources (family, income, free riding, etc.). There is no consensus in the literature concerning the influence of gender on energy literacy. Cotton et al. [20] found that women have lower levels of knowledge about sustainability but demonstrate more positive attitudes towards ecology and a greater willingness to change their habits, which may mean saving more energy. Also, Räty and Carlsson-Kanyama [21] found that women have higher energy literacy levels than men. Age may be linked to the responsibility of paying electricity expenses. Several young adults reported that they were more aware of their expenses if in charge of the payment of electricity expenses. Those who do not have energy expenses as their responsibility have little motivation to save energy [22,23]. Parents' influence and recommendations are often essential at these ages, allowing young people to develop more sustainable and efficient behaviors [24]. A higher level of education and the attendance of energy-related courses [6,7,25], as well as living in a favorable socio-economic context, may lead to higher levels of energy literacy. According to Filippini et al. [18], higher levels of energy-related financial literacy, namely better computing skills, lead to more rational attitudes towards buying and replacing household equipment and allowing for significant energy savings. Additionally, Boogen et al. [26] highlighted that people who have higher levels of energy-related financial literacy consume less energy. Finally, free-riding behavior seems to have a negative impact on energy literacy levels, as it discourages efforts to adopt energy savings [27].

Some other determinants have also been reported in the literature. The way information is displayed on equipment, mainly the equipment's annual energy expenditure, may also influence choices. If this information is presented in monetary terms, it becomes easier to understand and consequently more people may make a rational choice by choosing the most efficient equipment [19]. Another factor that may influence energy literacy is the method of payment of the electricity bill. If electricity is prepaid, consumers are more likely to consume more compared to if electricity were paid after consumption $[28,29]$. Besides this, risk aversion seems to reduce the probability of investment in energy efficiency [30] through the use of more efficient equipment or by investing in the self-production of energy.

In many purchase situations, the information regarding energy efficiency and future energy costs is less apparent than the purchase price [31]. Financial knowledge is important when consumers face a trade-off between efficiency and price/cost [4,13,31]. Blasch et al. [31] reported that a higher level of energy and investment literacy enhances an individual's probability of performing an investment calculation and choosing the most efficient appliance. There is also evidence in the literature that financial development positively and significantly impacts energy demand [32]. Likewise, the results of Blasch et al. [13], Filippini et al. [18] and Kumar [27] confirmed that women have lower levels of financial literacy than men, and if financial literacy is related to energy literacy, as we aim to analyze in 
this work, this may lead to a lower level of energy literacy. Therefore, the present article is based on a survey that includes financial knowledge questions to infer the effect of financial knowledge on energy literacy for members of a Portuguese university.

\section{Methodology and Data}

The most common methodology used in the literature to assess the energy literacy level is the questionnaire $[5,9,33,34]$. To build our questionnaire, we made use of previous works developed by DeWaters et al. [3], Kang et al. [35], Zografakis et al. [36], Kalmi et al. [14], Blasch et al. [37] and Lusardi and Mitchell [38], as well as an online questionnaire promoted by the Regional Energy Agency [39]. This online questionnaire promoted by the Regional Energy Agency was one of the results of the project "Knowing \& Acting-Platform for the measurement and dissemination of unbundled electrical consumption and benchmarking of electricity consumption in municipal administrative buildings" which was developed in co-promotion by Agência Regional de Energia-Barreiro, Moita, Montijo, Alcochete (S.ENERGIA) Agência Municipal de Energia do Seixal (AMESeixal), Agência Regional de Energia e Ambiente do Norte Alentejano e Tejo (AREANATejo) and Agência de Energia e Ambiente da Arrábida (ENA) and financed by the Electricity Consumption Promotion Plan (PPEC) 2013-2014/Energy Services Regulatory Entity (ERSE). This measure aimed at increasing citizens' awareness of the sustainable use of energy, through the provision of relevant information on energy performance in municipal administrative buildings, to municipal employees and residents. Based on the literature [3,14,35-39], we selected a set of questions to measure energy literacy, considering the assessment of knowledge regarding energy and finance, attitude and behavior.

We used 31 closed-answer questions to measure energy-related knowledge levels; we assigned one point for each correct answer and zero points for each incorrect answer (see the complete questionnaire on Appendix A). To measure energy-related financial knowledge, we used a set of four closed-answer questions, for which we followed the same methodology described above. We also included an open-ended question to measure energy price awareness by assessing participants' knowledge regarding the average price of $1 \mathrm{kWh}$ of electricity. For this last question, and considering that the correct value was 0.2150 Euros according to the information from PORDATA for 2019, we considered the answers between 0.15 and 0.27 Euros to be correct and for rewarded these with one point. To assess attitude and behavior, we used 19 and 11-scale questions, respectively, where the degree of agreement (or disagreement) with each of the statements presented was measured along with the frequency with which participants carried out the actions described. We assigned points between 1 and 5 according to the degree of agreement/disagreement. The frequency indicated was associated with positive attitudes and correct behaviors, with 1 being a negative attitude or incorrect behavior and 5 a positive attitude or correct behavior. Considering the works of Barrow and Morrisey [40], Armstrong and Impara [41], DeWaters and Powers [5], DeWaters et al. [3] and Lee et al. [9], we summed the points obtained for each question/statement and obtained the total rating for each dimension. To determine the level of energy literacy, we summed all these four ratings $[4,31]$. The maximum level of energy literacy that could be achieved was 186 points. Therefore, regarding levels of literacy, scores between 0 and 70 $(0-38 \%)$ were considered low, from 70 to $140(38-75 \%)$ were considered moderate, from 140 to 160 (75-86\%) were considered good and scores from 160 to 186 (86-100\%) were very good.

We also added some socio-demographic questions, such as age, education and qualification level, among others, based on the literature review on which factors may influence energy literacy to verify their impact and relevance on the Portuguese university members' (students, teachers, researchers and technicians) energy literacy levels. The questionnaire was distributed by email to the departmental administrators of some Portuguese universities, including a link to the online survey, hosted by "LimeSurvey". Data collection was carried out between January and April of 2020 and allowed 409 complete and valid responses. Of the respondents to this questionnaire, $30.81 \%$ were men and $69.19 \%$ were women. In total, $72.37 \%$ of the participants attended a higher education course, $58.44 \%$ lived in 
their own homes and $49.14 \%$ were responsible for the payment of electricity expenses. The complete questionnaire conducted for this research may be found in the Appendix A.

Regarding the methodology employed, and considering that dependent variables are expressed in relative terms, we used simple ordinary least squares (OLS) methods and the dependent variables were energy knowledge, energy attitude and energy behavior. Several estimation specifications are presented to infer the quality of results and for robustness checks. We also performed a stepwise regression methodology to achieve the best predictors of the three dimensions of energy literacy.

\section{Results}

This section presents empirical results and findings by presenting both descriptive statistics of the data and regression results. We start by observing the energy literacy level scores achieved.

\subsection{Energy Literacy Levels}

Energy literacy levels are represented in Figure 1. Regarding our classification of levels of literacy, where $0-38 \%$ is considered low, $38-75 \%$ is considered moderate, $75-86 \%$ is considered good and $86-100 \%$ very good, we found that the Portuguese university community had, at the time of our survey, good energy attitudes (77.193 points/81.256\%), energy behavior (43.789 points/79.616\%) and energy literacy (143.914 points/77.373\%). However, their level of knowledge was moderate, both in terms of energy (20.359 points/65.674\%) and financial (2.257 points/56.418\%) knowledge. In turn, energy price awareness was found to be low. The issues that seem to cause the most difficulties for Portuguese university community members are questions related to the goals defined by public entities for the reduction of carbon dioxide emissions and energy consumption, to which energy sources contribute the most to the energy consumed in Portugal and to the average price of $1 \mathrm{kWh}$ of electricity. This result is consistent with the conclusions reported by Kalmi et al. [15], who mentioned that a small part of the participants-less than a quarter-in their sample provided correct answers regarding the price of electricity.

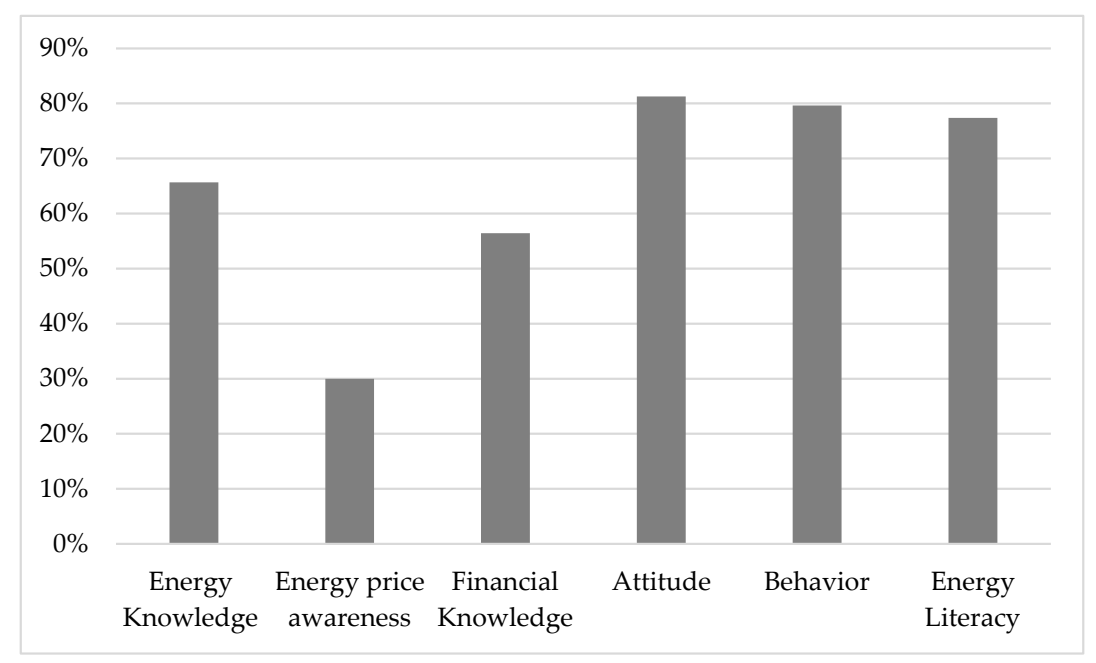

Figure 1. Energy and financial knowledge, energy price awareness, attitude, behavior and energy literacy levels.

\subsection{Determinants for Energy Literacy Dimensions}

Table 1 presents Pearson correlation values between dependent and independent variables for the previously mentioned factors that the literature has referred to as potential influencers of energy literacy dimensions. It is possible to conclude that none of the correlation values presented are sufficiently high to justify the presence of multicollinearity among independent variables. Even so, the regression results included different specifications for the variables to ensure the robustness of our results. 
Table 1. Correlations between variables.

\begin{tabular}{|c|c|c|c|c|c|c|c|c|c|c|c|}
\hline & Gender & Age & Ln(Age) & $\begin{array}{c}\text { Education } \\
\text { Level }\end{array}$ & Home & Responsibility & $\begin{array}{c}\text { Energy } \\
\text { Knowledge }\end{array}$ & $\begin{array}{c}\text { Energy Price } \\
\text { Awareness }\end{array}$ & $\begin{array}{c}\text { Financial } \\
\text { Knowledge }\end{array}$ & Attitude & Behavior \\
\hline Gender & 1.000 & & & & & & & & & & \\
\hline Age & $\begin{array}{c}-0.215^{* * *} \\
(0.000)\end{array}$ & 1.000 & & & & & & & & & \\
\hline $\begin{array}{c}\text { Ln } \\
\text { (Age) }\end{array}$ & $\begin{array}{c}-0.201 * * * \\
(0.000)\end{array}$ & $\begin{array}{c}0.986^{* * *} \\
(0.000)\end{array}$ & 1.000 & & & & & & & & \\
\hline Education level & $\begin{array}{c}-0.095^{*} \\
(0.055)\end{array}$ & $\begin{array}{c}0.549 * * * \\
(0.000)\end{array}$ & $\begin{array}{c}0.610 * * * \\
(0.000)\end{array}$ & 1.000 & & & & & & & \\
\hline Home & $\begin{array}{l}-0.026 \\
(0.607)\end{array}$ & $\begin{array}{c}0.228^{* * *} \\
(0.000)\end{array}$ & $\begin{array}{c}0.207^{* * *} \\
(0.000)\end{array}$ & $\begin{array}{c}0.005 \\
(0.926)\end{array}$ & 1.000 & & & & & & \\
\hline Responsibility & $\begin{array}{c}-0.117 \text { ** } \\
(0.018)\end{array}$ & $\begin{array}{c}0.488^{* * *} \\
(0.000)\end{array}$ & $\begin{array}{c}0.513^{* * *} \\
(0.000)\end{array}$ & $\begin{array}{c}0.341^{* * *} \\
(0.000)\end{array}$ & $\begin{array}{c}-0.193 \text { *** } \\
(0.000)\end{array}$ & 1.000 & & & & & \\
\hline $\begin{array}{c}\text { Energy } \\
\text { knowledge }\end{array}$ & $\begin{array}{c}-0.211^{* * *} \\
(0.000)\end{array}$ & $\begin{array}{c}0.191 \text { *** } \\
(0.000)\end{array}$ & $\begin{array}{c}0.178^{* * *} \\
(0.000)\end{array}$ & $\begin{array}{c}0.189 * * * \\
(0.000)\end{array}$ & $\begin{array}{c}0.075 \\
(0.131)\end{array}$ & $\begin{array}{c}0.033 \\
(0.511)\end{array}$ & 1.000 & & & & \\
\hline $\begin{array}{c}\text { Energy price } \\
\text { awareness }\end{array}$ & $\begin{array}{c}-0.174^{* * *} \\
(0.000)\end{array}$ & $\begin{array}{c}0.235^{* * *} \\
(0.000)\end{array}$ & $\begin{array}{c}0.252 * * * \\
(0.000)\end{array}$ & $\begin{array}{c}0.155^{* * *} \\
(0.002)\end{array}$ & $\begin{array}{l}0.113^{* *} \\
(0.022)\end{array}$ & $\begin{array}{c}0.154^{* * *} \\
(0.002)\end{array}$ & $\begin{array}{c}0.252 * * * \\
(0.000)\end{array}$ & 1.000 & & & \\
\hline $\begin{array}{c}\text { Financial } \\
\text { knowledge }\end{array}$ & $\begin{array}{c}-0.253^{* * *} \\
(0.000)\end{array}$ & $\begin{array}{c}0.272 * * * \\
(0.000)\end{array}$ & $\begin{array}{c}0.287^{* * *} \\
(0.000)\end{array}$ & $\begin{array}{c}0.225^{* * *} \\
(0.000)\end{array}$ & $\begin{array}{c}0.050 \\
(0.310)\end{array}$ & $\begin{array}{c}0.170^{* * *} \\
(0.000)\end{array}$ & $\begin{array}{c}0.399 * * * \\
(0.000)\end{array}$ & $\begin{array}{c}0.253^{* * *} \\
(0.000)\end{array}$ & 1.000 & & \\
\hline Attitude & $\begin{array}{l}0.123 * * \\
(0.013)\end{array}$ & $\begin{array}{c}0.020 \\
(0.689)\end{array}$ & $\begin{array}{c}0.023 \\
(0.647)\end{array}$ & $\begin{array}{c}0.072 \\
(0.144)\end{array}$ & $\begin{array}{c}0.026 \\
(0.604)\end{array}$ & $\begin{array}{c}0.024 \\
(0.626)\end{array}$ & $\begin{array}{c}0.179^{* * *} \\
(0.000)\end{array}$ & $\begin{array}{l}0.096^{*} \\
(0.052)\end{array}$ & $\begin{array}{l}0.098^{* *} \\
(0.047)\end{array}$ & 1.000 & \\
\hline Behavior & $\begin{array}{l}0.111^{*} \\
(0.025)\end{array}$ & $\begin{array}{l}-0.019 \\
(0.699)\end{array}$ & $\begin{array}{l}-0.011 \\
(0.821)\end{array}$ & $\begin{array}{l}-0.031 \\
(0.537)\end{array}$ & $\begin{array}{c}0.043 \\
(0.386)\end{array}$ & $\begin{array}{l}-0.029 \\
(0.556)\end{array}$ & $\begin{array}{c}0.190^{* * *} \\
(0.000)\end{array}$ & $\begin{array}{l}0.117^{* *} \\
(0.018)\end{array}$ & $\begin{array}{l}0.103 \text { ** } \\
(0.037)\end{array}$ & $\begin{array}{c}0.447^{* * *} \\
(0.000)\end{array}$ & 1.000 \\
\hline
\end{tabular}

Source: Own elaboration with Stata 16 . Note: $p$-values are in parenthesis; ${ }^{*}{ }^{* * *}{ }^{* * *}$ refer, respectively, to the $10 \%, 5 \%$ and $1 \%$ significance levels. 
At first sight, we may argue that there is a negative correlation between gender and each of the other variables-age, education, responsibility, energy knowledge and financial knowledge-except attitude and behavior. The same may be said for the education level. Moreover, financial knowledge seems to be positively and significantly correlated with responsibility, energy knowledge, attitude and behavior; thus, with all the components of energy literacy and energy literacy itself. With the regression results, which are presented next, we aim to confirm some of these correlation signs. This means that financial knowledge should increase the energy literacy levels of individuals, and this might be important information to advise policymakers that financial knowledge cannot be dissociated from other types of knowledge.

Table 2 presents the first set of regression results exploring the factors influencing energy literacy in its three dimensions (knowledge, attitude and behavior). It is possible to stress the negative effect of gender over knowledge and a positive and significant impact of gender on attitude and behavior. Considering the way this variable was included in the survey, where 1 stood for females and 0 for males, we may argue from the results that women have better energy attitudes and energy behavior, while men have better energy knowledge.

Table 2. Ordinary least squares (OLS) estimations result for energy literacy dimensions: knowledge, attitude and behavior.

\begin{tabular}{|c|c|c|c|c|c|c|}
\hline \multirow[b]{2}{*}{ Constant } & \multicolumn{2}{|c|}{ Knowledge } & \multicolumn{2}{|c|}{ Attitude } & \multicolumn{2}{|c|}{ Behavior } \\
\hline & $\begin{array}{c}0.5322 * * * \\
(0.000)\end{array}$ & $\begin{array}{c}0.5342^{* * *} \\
(0.000)\end{array}$ & $\begin{array}{c}0.7133^{* * *} \\
(0.000)\end{array}$ & $\begin{array}{c}0.7466^{* * *} \\
(0.000)\end{array}$ & $\begin{array}{c}0.7048^{* * *} \\
(0.000)\end{array}$ & $\begin{array}{c}0.7097^{* * *} \\
(0.000)\end{array}$ \\
\hline Gender & $\begin{array}{c}-0.0295^{* *} \\
(0.037)\end{array}$ & $\begin{array}{c}-0.0309 * * \\
(0.029)\end{array}$ & $\begin{array}{c}0.0288^{* * *} \\
(0.000)\end{array}$ & $\begin{array}{c}0.0288^{* * *} \\
(0.000)\end{array}$ & $\begin{array}{c}0.0318^{* * *} \\
(0.001)\end{array}$ & $\begin{array}{c}0.0322 * * * * \\
(0.001)\end{array}$ \\
\hline Age & $\begin{array}{l}0.0005 \\
(0.461)\end{array}$ & & $\begin{array}{c}-0.0003 \\
(0.408)\end{array}$ & & $\begin{array}{c}-0.0002 \\
(0.661)\end{array}$ & \\
\hline $\begin{array}{l}\text { Ln } \\
\text { (Age) }\end{array}$ & & $\begin{array}{l}0.0003 \\
(0.991)\end{array}$ & & $\begin{array}{c}-0.0139 \\
(0.353)\end{array}$ & & $\begin{array}{c}-0.0023 \\
(0.895)\end{array}$ \\
\hline Education level & $\begin{array}{l}0.0070^{*} \\
(0.073)\end{array}$ & $\begin{array}{c}0.0082^{* *} \\
(0.045)\end{array}$ & $\begin{array}{l}0.0020 \\
(0.369)\end{array}$ & $\begin{array}{l}0.0023 \\
(0.321)\end{array}$ & $\begin{array}{c}-0.0028 \\
(0.276)\end{array}$ & $\begin{array}{c}-0.0031 \\
(0.250)\end{array}$ \\
\hline Home & $\begin{array}{l}0.0021 \\
(0.880)\end{array}$ & $\begin{array}{l}0.0059 \\
(0.673)\end{array}$ & $\begin{array}{l}0.0039 \\
(0.620)\end{array}$ & $\begin{array}{l}0.0042 \\
(0.597)\end{array}$ & $\begin{array}{l}0.0045 \\
(0.627)\end{array}$ & $\begin{array}{l}0.0034 \\
(0.709)\end{array}$ \\
\hline Responsibility & $\begin{array}{c}-0.0307^{* *} \\
(0.044)\end{array}$ & $\begin{array}{c}-0.0258 * \\
(0.096)\end{array}$ & $\begin{array}{l}0.0052 \\
(0.551)\end{array}$ & $\begin{array}{l}0.0058 \\
(0.510)\end{array}$ & $\begin{array}{c}-0.0001 \\
(0.995)\end{array}$ & $\begin{array}{c}-0.0013 \\
(0.900)\end{array}$ \\
\hline Energy price awareness & $\begin{array}{c}0.0431^{* * *} \\
(0.002)\end{array}$ & $\begin{array}{c}0.0438^{* * *} \\
(0.002)\end{array}$ & $\begin{array}{l}0.0104 \\
(0.200)\end{array}$ & $\begin{array}{l}0.0107 \\
(0.190)\end{array}$ & $\begin{array}{c}0.0173^{*} \\
(0.065)\end{array}$ & $\begin{array}{l}0.0172 * \\
(0.068)\end{array}$ \\
\hline Financial knowledge & $\begin{array}{c}0.1434^{* * *} \\
(0.000)\end{array}$ & $\begin{array}{c}0.1449^{* * *} \\
(0.000)\end{array}$ & $\begin{array}{l}0.0124 \\
(0.335)\end{array}$ & $\begin{array}{l}0.0128 \\
(0.322)\end{array}$ & $\begin{array}{c}0.0184 \\
(0.217))\end{array}$ & $\begin{array}{l}0.0181 \\
(0.226)\end{array}$ \\
\hline Energy knowledge & & & $\begin{array}{c}0.0928^{* * *} \\
(0.001)\end{array}$ & $\begin{array}{c}0.0919^{* * *} \\
(0.001)\end{array}$ & $\begin{array}{c}0.1166^{* * *} \\
(0.000)\end{array}$ & $\begin{array}{c}0.1161 \text { *** } \\
(0.000)\end{array}$ \\
\hline R-squared & 0.2095 & 0.2084 & 0.0701 & 0.0705 & 0.0776 & 0.0772 \\
\hline $\mathrm{F}$ & 15.18 & 15.08 & 3.77 & 3.79 & 4.20 & 4.18 \\
\hline Prob $>$ F & 0.0000 & 0.0000 & 0.0003 & 0.0003 & 0.0001 & 0.0001 \\
\hline
\end{tabular}

Source: Own elaboration with Stata 16 . Note: $p$-values are in parenthesis; ${ }^{*}, * *, * * *$ refer, respectively, to the $10 \%, 5 \%$ and $1 \%$ significance levels.

Education level only seems to positively and significantly influence energy knowledge, independently of the specification adopted for the age variable, which was not found to be significant for any of the energy literacy dimensions. The association between education level and energy knowledge was an expected result, considering the meaning of the two variables.

Regarding responsibility, the results seem to indicate a slightly negative and significant influence on energy knowledge. Therefore, the higher the responsibility of the individual, the lower the energy knowledge demonstrated. 
Our main research question was whether financial knowledge influences energy literacy, and the results are quite clear: it has a positive and significant influence on energy literacy. Therefore, we may argue in favor of the increased effects of financial knowledge over energy literacy, at least in one of its dimensions.

Regarding energy price awareness, our results show a positive and significant impact on both knowledge and behavior. However, the influence on knowledge seems to be higher than the influence on behavior.

Another interesting result that may be found from the results in Table 2 is that energy knowledge seems to influence attitude and behavior positively and significantly, regardless of the age measure used. Thus, knowledge seems to be important to justify the attitude and behavior of individuals and contributes significantly to energy literacy levels. These results also corroborate the initially presented conclusions regarding Pearson correlation coefficients.

We removed age from our estimations since it was not found to be a relevant variable, and the results may be found in Table 3. Some patterns remain: being female still seems to have a positive influence on attitude and behavior and a negative impact on energy knowledge. Education level seems to have a positive effect on energy knowledge; however, in this table, it shows a negative and significant impact on behavior when the variable of attitude is added to estimations as a way to explain energy literacy, whose effect (energy attitude) seems to be positive and highly significant on energy behavior.

Table 3. OLS estimation results for energy literacy dimensions-knowledge, attitude and behavior-using different specifications.

\begin{tabular}{|c|c|c|c|c|c|}
\hline \multirow[b]{2}{*}{ Constant } & \multirow{2}{*}{$\begin{array}{c}\text { Energy Knowledge } \\
0.535^{* * *} \\
(0.000)\end{array}$} & \multirow{2}{*}{$\begin{array}{c}\text { Energy Knowledge } \\
0.602 * * * \\
(0.000)\end{array}$} & \multirow{2}{*}{$\begin{array}{c}\text { Attitude } \\
0.712^{* * *} \\
(0.000)\end{array}$} & \multicolumn{2}{|c|}{ Behavior } \\
\hline & & & & $\begin{array}{c}0.704^{* * *} \\
(0.000)\end{array}$ & $\begin{array}{c}0.365 * * * \\
(0.000)\end{array}$ \\
\hline Gender & $\begin{array}{c}-0.0309 \text { ** } \\
(0.027)\end{array}$ & $\begin{array}{c}-0.059^{* * *} \\
(0.000)\end{array}$ & $\begin{array}{c}0.030 * * * \\
(0.000)\end{array}$ & $\begin{array}{c}0.032 * * * \\
(0.001)\end{array}$ & $\begin{array}{l}0.018^{* *} \\
(0.034)\end{array}$ \\
\hline Education level & $\begin{array}{l}0.008^{* *} \\
(0.017)\end{array}$ & $\begin{array}{l}0.013^{* * * *} \\
(0.000)\end{array}$ & $\begin{array}{c}0.001 \\
(0.554)\end{array}$ & $\begin{array}{l}-0.003 \\
(0.150)\end{array}$ & $\begin{array}{c}-0.004 * \\
(0.066)\end{array}$ \\
\hline Home & $\begin{array}{c}0.006 \\
(0.647)\end{array}$ & $\begin{array}{c}0.017 \\
(0.212)\end{array}$ & $\begin{array}{c}0.001 \\
(0.839)\end{array}$ & $\begin{array}{c}0.003 \\
(0.727)\end{array}$ & $\begin{array}{c}0.002 \\
(0.771)\end{array}$ \\
\hline Responsibility & $\begin{array}{l}-0.026^{*} \\
(0.060)\end{array}$ & $\begin{array}{l}-0.012 \\
(0.426)\end{array}$ & $\begin{array}{c}0.002 \\
(0.799)\end{array}$ & $\begin{array}{l}-0.002 \\
(0.833)\end{array}$ & $\begin{array}{l}-0.003 \\
(0.729)\end{array}$ \\
\hline Energy knowledge & & & $\begin{array}{c}0.092 * * * \\
(0.001)\end{array}$ & $\begin{array}{c}0.116^{* * *} \\
(0.000)\end{array}$ & $\begin{array}{l}0.072 * * \\
(0.017)\end{array}$ \\
\hline Financial knowledge & $\begin{array}{c}0.145^{* * *} \\
(0.000)\end{array}$ & & $\begin{array}{c}0.012 \\
(0.366)\end{array}$ & $\begin{array}{c}0.018 \\
(0.228)\end{array}$ & $\begin{array}{c}0.012 \\
(0.361)\end{array}$ \\
\hline Energy price awareness & $\begin{array}{c}0.044^{* * *} \\
(0.002)\end{array}$ & & $\begin{array}{c}0.010 \\
(0.217)\end{array}$ & $\begin{array}{l}0.017^{*} \\
(0.068)\end{array}$ & $\begin{array}{c}0.012 \\
(0.149)\end{array}$ \\
\hline Attitude & & & & & $\begin{array}{c}0.476^{* * *} \\
(0.000)\end{array}$ \\
\hline R-squared & 0.208 & 0.080 & 0.069 & 0.077 & 0.233 \\
\hline $\mathrm{F}$ & 17.64 & 8.73 & 4.21 & 4.79 & 15.19 \\
\hline Prob $>$ F & 0.000 & 0.000 & 0.000 & 0.000 & 0.000 \\
\hline
\end{tabular}

Source: Own elaboration with Stata 16. Note: $p$-values are in parenthesis; ${ }^{*}, * * * * *$ refer, respectively, to the $10 \%$, $5 \%$ and $1 \%$ significance levels.

When age and financial knowledge are removed from the estimations, responsibility seems to lose significance on energy knowledge. Although the factor "home" was previously shown to have a positive effect, this was found to be statistically insignificant for all of the energy literacy dimensions. Only financial knowledge continues to positively influence energy knowledge. 
Energy price awareness seems to continue to positively and significantly influence energy knowledge and energy behavior but seems to lose significance when attitude is added to the estimates of energy behavior.

To confirm these results and determine the variables that best explain the variation of the three energy literacy dimensions, we performed stepwise estimations (all steps are demonstrated in Appendix B). From the results obtained, showed in Table 4, we conclude that financial knowledge and energy price awareness are the variables that best explain energy knowledge, energy knowledge and gender are the variables that best explain attitude, and energy knowledge and attitude are the best predictors of behavior.

Table 4. Best models according to stepwise estimation.

\begin{tabular}{|c|c|c|c|}
\hline & Energy Knowledge & Attitude & Behavior \\
\hline Constant & $\begin{array}{c}0.551^{* * *} \\
(0.000)\end{array}$ & $\begin{array}{c}0.721^{* * *} \\
(0.000)\end{array}$ & $\begin{array}{c}0.347^{* * *} \\
(0.000)\end{array}$ \\
\hline Gender & & $\begin{array}{c}0.026 \text { *** } \\
(0.001)\end{array}$ & \\
\hline Energy knowledge & & $\begin{array}{c}0.112 \text { *** } \\
(0.000)\end{array}$ & $\begin{array}{l}0.069 * * \\
(0.011)\end{array}$ \\
\hline Financial knowledge & $\begin{array}{c}0.160 * * * \\
(0.000)\end{array}$ & & \\
\hline Energy price awareness & $\begin{array}{c}0.048^{* * *} \\
(0.001)\end{array}$ & & \\
\hline Attitude & & & $\begin{array}{c}0.496^{* * *} \\
(0.000)\end{array}$ \\
\hline R-squared & 0.1836 & 0.0591 & 0.2125 \\
\hline $\mathrm{F}$ & 45.65 & 12.75 & 54.78 \\
\hline Prob $>$ F & 0.0000 & 0.0000 & 0.000 \\
\hline
\end{tabular}

Source: Own elaboration with Stata 16. Note: $p$-values are in parenthesis; ${ }^{*}, * * * * *$ refer, respectively, to the $10 \%$, $5 \%$ and $1 \%$ significance levels.

Considering all these results, we can explain the rationale behind the policy implications of energy literacy. Although our concluding results refer to a specific sample of Portuguese university members, they provide interesting avenues of future research for other country contexts, especially those evidencing the same kind of consumer knowledge, attitude and behavior regarding energy issues. Moreover, the energy-related financial knowledge included in our study refers to financial knowledge related to energy matters. It would be interesting in future to account for all financial literacy dimensions and verify the interaction between energy and financial literacy.

\section{Discussion}

The empirical analysis presented above provides several interesting results, some of which have not been reported in previous literature to the best of our knowledge. First, it has been proved that financial knowledge is a relevant factor for energy literacy since it exerts a positive influence on energy knowledge. Second, it has been proved that there is a direct and positive relationship between all the three dimensions of energy literacy: knowledge, attitude and behavior. Third, gender significantly influences all the three energy literacy dimensions: being female positively influences attitude and behavior, whereas it negatively influences the knowledge component.

Following DeWaters et al. [3], energy literacy encompasses three main dimensions, which have been analyzed in the present work. Energy knowledge involves the domain of basic energy concepts and understanding how energy is produced, distributed and consumed, the influence of energy flows and the role of energy in ecosystems. Our empirical results demonstrate that women have lower 
poorer energy knowledge than men. However, regarding energy attitude (citizens' perceptions of the influence that energy issues have on human life and each person's beliefs and ideologies regarding energy) and energy behavior (personal awareness of the impact of day-to-day actions, adoption of energy-saving habits and conscious decision making), the results seem to indicate that women have a better attitude and behavior. In the literature, we find the opposite results regarding the influence of gender. Our results confirm those of Cotton et al. [20], who also found that women have lower levels of knowledge regarding sustainability but demonstrate more positive attitudes towards ecology and a greater willingness to change their habits, which may mean saving more energy and therefore better behavior. We can also partly confirm the results of Brounen et al. [34], who showed that men have more energy awareness and literacy. Thus, our results seem to indicate that women have lower levels of energy knowledge than men, but that women show a better attitude and behavior.

Regarding the effects of financial knowledge on energy literacy, the results were also clear: financial knowledge leads to higher energy knowledge. Therefore, financial knowledge increases consciousness and improves energy knowledge, but it does not significantly influence individuals' attitude or behavior. Even if it has a positive effect on attitude and behavior, the results are not significant, and this may be related to the fact that costs or prices are highly weighted as compared to energy efficiency habits. These are intrinsic to the decision-making process of the consumer; therefore, future research could include individuals' income in the analysis, since it would be interesting to observe how the three variables behave jointly. As such, in the moment of choosing between the lowest-priced and the most efficient equipment, the results seem to suggest that price still wins out. Therefore, our results contradict those of Blasch et al. [31], who found that a higher level of energy and investment literacy enhances the individuals' probability of performing an investment calculation and choosing the most efficient appliance. However, it seems to be proven that financial knowledge is important when consumers face a trade-off between efficiency and price/cost, as shown by Martins et al. [4], Blasch et al. [13], and Blasch et al. [31].

Concerning the level of education, the existing literature showed that a higher level of education improves the levels of energy literacy, mainly due to increased knowledge $[6,7,25]$. Our results also confirm this, with education level exerting a positive and significant impact on energy knowledge.

Energy price awareness positively and significantly influences energy knowledge and energy behavior but seems to lose significance when we add attitudes to estimate their impact on energy behavior. Provided that the energy price awareness level revealed in our sample is low (Figure 1), this may inform policymakers about the potential lack of appropriate available information. However, there could also be a lack of willingness on the part of consumers to search for price information or a lack of knowledge regarding where to find it. Thus, more information transparency regarding energy prices seems to be required to improve these dimensions, given its significant impact over both energy knowledge and energy behavior. If consumers, in fact, give more weight to the price or cost of energy in their decision process compared to energy efficiency, perhaps increasing price awareness would lead to more conscious behaviors and consequent improvements in energy literacy. According to Cotton et al. [42], informal relationships with housemates, friends or partners may significantly influence attitudes and behaviors. Some individuals that live in shared homes may argue that they are not able to make efficient use of their electricity because they share their house with other colleagues and use the appliances that have already been installed in the house by the landlord, and therefore they do not have the opportunity to substitute them for more recent and more efficient appliances. However, our results show that people living in their own home or living in a rented house does not seem to have a significant influence on energy literacy dimensions.

Finally, regarding responsibility, Dianshu et al. [29] and Brutscher [28] concluded that being responsible for paying the electricity bill generally makes citizens more aware of the price of electricity and the monthly expenditure on electricity, thus improving the levels of energy literacy. Our results seem to contradict this idea, showing a slightly negative and significant influence on energy knowledge. Perhaps these results may be explained in two different ways: first, because the people responsible for 
paying the electricity expenses concluded their studies several years ago, when the question of saving energy and having sustainable behavior had not yet arisen, and the school therefore did not provide sufficient information on these topics; second, these people already have more defined habits and are more resistant to change.

\section{Conclusions}

Considering the growing importance of environmental issues such as global warming or the shortage of fossil fuels, it is becoming increasingly important to keep people informed, aware and motivated to save resources. In this sense, the assessment of energy literacy levels may contribute positively to the awareness of individuals not only regarding the need to adopt sustainable behaviors but also providing relevant inputs regarding the factors that influence energy literacy levels, helping to diagnose which areas need more work and which policies should be adopted to improve literacy.

From our analysis, we may conclude that Portuguese university members in 2020 seem to have good levels of energy literacy; however, there is still room for improvement, particularly concerning knowledge. Our results also show that despite women being revealed to have a lower level of knowledge than men, they show a higher level of attitude and a higher level of energy behavior than their male counterparts. Level of education seems to have a positive and significant impact on energy knowledge, while living in one's own home and being responsible for the payment of electricity expenses seems not to have an impact on the energy literacy dimensions. Energy price awareness seems to have a positive and significant impact on knowledge and behavior; however, when we introduce attitude to estimate behavior, it loses significance. Finally, the financial knowledge related to energy issues seems to show a significant relationship with energy knowledge, highlighting the need to promote both types of knowledge.

Our study has two major limitations: the reduced dimension of the sample, as compared to the total population in Portugal, and the way we measured behavior may be questioned. Considering the dimension of the sample, we tried to invite as many people as possible, using the institutional mechanisms of the Portuguese universities, to fill in our questionnaire. However in the end, questionnaires were only an option for students, teachers or technician, and researchers could not control this process. Considering this limitation, we cannot fully generalize our results to the entire population, but we can infer some relevant results for this sample. Regarding the measurement of the behavior, we are aware that asking for a person to report their actions concerning energy is not equal to observing their real behavior; however, this is the most common way to measure behavior in the literature. The same applies to financial knowledge measurement. The questions used in the questionnaire regarding financial knowledge capture only a narrow aspect of financial knowledge, but this serves our purposes of verifying whether financial knowledge might influence energy literacy levels. We thank the reviewer of this article for having called our attention to this fact. The esults confirm that financial knowledge, in the way we measured it, at least positively influences energy knowledge, confirming previous findings [14,20,32], using questions to measure it based on the definition of financial knowledge [38].

Considering these results, we suggest that policymakers should support an increased frequency of energy and finance-related courses for all students, or perhaps make these courses mandatory at all levels of education, with the aim of improving the knowledge, attitude and behavior of future generations. Sustainable behaviors need to be introduced at an early age in the hope that these would help to develop energy-saving behaviors in the future.

For further research, we suggest the investigation of other factors that might influence energy literacy dimensions, such as the concerns about free riding, the scientific area of education, income, or the type of job, etc. Additionally, new ways to assess behavior may be proposed; for example, using lab experiments or gaming to assess the impact of some energy workshops or activities on energy literacy. 
Author Contributions: Conceptualization, methodology, validation, formal analysis, investigation, writing-original draft preparation, A.M., M.M. and M.F.D.; Software, data treatment, estimations, A.M.; Writing-review and editing, M.M. and M.F.D.; Supervision, M.M. and M.F.D. All authors have read and agreed to the published version of the manuscript.

Funding: This research received no external funding.

Acknowledgments: This work was supported by the research unit on Governance, Competitiveness and Public Policy (UIDB/04058/2020), funded by national funds through FCT—Fundação para a Ciência e a Tecnologia.

Conflicts of Interest: The authors declare no conflict of interest.

\section{Appendix A}

\section{Energy Literacy Questionnaire}

This study aims to collect data within the framework of a Ph.D. thesis in Economic and Business Sciences taught at DEGEIT, University of Aveiro. The questionnaire complies with the stipulations of the General Data Protection Regulation (GDPR), ensuring the security, protection, anonymity and confidentiality of all data provided by the participants at all stages. The data will be kept until the thesis defense date, after which they will be destroyed.

The questionnaire has an average response time of about $15 \mathrm{~min}$.

The success of this study depends a grea deal on your collaboration, for which we thank you in advance.

\section{Personal Information}

Gender: Male Female

Age:

Residence council:

Academic training:

\begin{tabular}{c}
\hline Elementary School-1st cycle (4th year) \\
\hline Basic Education-2nd cycle (6th grade) \\
\hline Basic education-3rd cycle (9th grade) \\
\hline Secondary Education (12th grade) \\
\hline CET-technological specialization course \\
\hline CTeSP—Professional Technical College \\
Bachelor's degree \\
\hline Master's degree \\
PhD \\
\hline Post-doc
\end{tabular}

If you had a superior course, please indicate the area of your course: Profession:

\begin{tabular}{ccc}
\hline Student & \\
\hline Self-employed & \\
\hline & \multicolumn{1}{c}{ Private Sector } & \\
\cline { 2 - 3 } Employee & Public Sector & Investigator \\
& & Technician \\
\cline { 2 - 2 } & \\
\hline Retired & Other \\
\hline Domestic & \\
\hline Unemployed & \\
\hline
\end{tabular}


At your workplace, do you have access to electricity bill information? Yes__ No

Do you have reminders in the workplace that help you remember to save energy (e.g., turn off the light)? Yes No

Do you live in your own house or rent a house?

Own house___ Rented house

If you live in a rented house/room, are energy expenses included in the rent? Yes No

Are you responsible for paying the energy bills? Yes No

Number of household appliances other than your own:

\section{Questions}

1. Energy is defined as:

(a) The force that sets bodies in motion

(b) Material that can be observed

(c) Ability to do work

(d) Don't know

2. The amount of electrical energy (electricity) we use is measured in units called ...
(a) Watts (W)
(b) Kilowatt-hours (kWh)
(c) Joules (J)
(d) Don't know

3. The amount of energy consumed by an electrical appliance is equal to ...
(a) The power rating of the appliance (watts or kilowatts)
(b) The power rating of the appliance (watts or kilowatts) multiplied by the time it is used
(c) The price of electricity multiplied by the time of use of the appliance
(d) Don't know

4. The two things that determine the amount of electrical energy (electricity) an electrical appliance will consume are...
(a) The power rating of the appliance (watts or kilowatts), and the price of electricity
(b) The capacity of the equipment and the length of time the appliance is turned on
(c) The power rating of the appliance (watts or kilowatts), and the length of time is turned on
(d) Don't know

5. The energy conversion precess for a battery-powered flashlight is
(a) Chemical energy $\rightarrow$ Electric energy $\rightarrow$ Light energy
(b) Nuclear energy $\rightarrow$ Electric energy $\rightarrow$ Light energy
(c) Electric energy $\rightarrow$ Light energy $\rightarrow$ Thermal energy
(d) Don't know

6. We know that a piece of wood stores potential chemical energy because
(a) It consists of matter
(b) May be burned
(c) It releases heat when burned
(d) Don't know

7. All of the following are forms of energy except
(a) Radiant
(b) Coal 
(c) Chemistry

(d) Don't know

8. When you turn on an incandescent light bulb, the following energy conversions take place
(a) Chemical energy for radiant energy (light) and thermal energy (heat)
(b) Electrical energy for radiant energy (light) and thermal energy (heat)
(c) Electrical energy for radiant energy (light)
(d) Don't know

9. When you turn on an incandescent light bulb, some of the energy is converted into light and the rest is converted into
(a) Electricity
(b) Heat
(c) Waste
(d) Don't know

10. What does it mean if an electric power plant is $35 \%$ efficient?
(a) In one hour, it produces 35 units of electrical energy
(b) For every 20 units of energy that go into the plant, 5 units are converted into electrical energy
(c) For every 100 units of energy that go into the plant, 35 units are converted into electrical energy
(d) Don't know

11. It is impossible to
(a) Build a machine that produces less than half the energy it uses
(b) Build a machine that produces more energy than it uses
(c) Build a machine that produces more than half the amount of energy it uses.
(d) Don't know

12. The original source of energy for almost all living things is
(a) Oxygen
(b) Petroleum
(c) Sun
(d) Don't know

13. The term "renewable energy sources" means

(a) Resources that cannot be replenished by nature

(b) Resources that can be replenished by nature

(c) Resources which may be replenished by nature, but the process takes years

(d) Don't know

14. What is the commitment to reducing carbon dioxide (CO2) emissions for the signatory cities of the Covenant of Mayors by 2020?
(a) $40 \%$
(b) $30 \%$
(c) $20 \%$
(d) Don't know

15. Which of the following energy resources is NOT renewable?
(a) Biomass
(b) Mineral coal
(c) Wind 


\section{(d) Don't know}

16. What is the main objective of Sustainable Development?
(a) Meet current needs without jeopardizing the needs of future generations
(b) Meet the needs of future generations without meeting present needs
(c) Seek to respond to today's needs without thinking about the future
(d) Don't know

17. Many useful manufactured products are made out of which one of the following energy resources?
(a) Coal
(b) Wind
(c) Petroleum
(d) Don't know

18. Most of the renewable energy used to produce electricity in Portugal comes from
(a) Solar energy
(b) Petroleum
(c) Wind energy
(d) Don't know

19. Which energy resource provides less than $50 \%$ of the energy used in Portugal?
(a) Renewable energy
(b) Fossil fuels
(c) None
(d) Don't know

20. Which of the following is NOT a biofuel?
(a) Biodiesel
(b) Gasoline
(c) Bioethanol
(d) Don't know

21. Within the scope of the Portuguese Energy Policy, particularly the National Action Plan for Energy Efficiency (PNAEE 2016), the 2020 targets for the reduction of primary energy consumption in Public Administration are:
(a) $40 \%$
(b) $30 \%$
(c) $20 \%$
(d) Don't know

22. Which of the following always saves energy?
(a) Turning off the car engine when the car is stopped for $15 \mathrm{~s}$ or more
(b) Turning off the car engine when the car is stopped for $10 \mathrm{~s}$ or less
(c) Turning off the car engine when the car is stopped for $10 \mathrm{~s}$ or more
(d) Don't know

23. If a person commuted alone to work $45 \mathrm{~km}$ every day and wanted to save gasoline, which one of the following options would save the MOST gasoline?

(a) Buy a car that consumes less fuel

(b) Carpooling to go and come from work with one other person 
(c) Maintain an adequate speed to save fuel

(d) Don't know

24. What are the recommended temperatures for a comfortable environment and not waste energy with the air conditioning system?
(a) Heat to $20^{\circ} \mathrm{C}$ and cool to $25^{\circ} \mathrm{C}$
(b) Heat to $22^{\circ} \mathrm{C}$ and cool to $27^{\circ} \mathrm{C}$
(c) Heat to $15{ }^{\circ} \mathrm{C}$ and cool to $20^{\circ} \mathrm{C}$
(d) Don't know

25. Given the energy label of a device, which class uses the least energy?
(a) $\mathrm{A}+$
(b) $\mathrm{C}$
(c) $\mathrm{E}$
(d) Don't know

26. What is the most efficient lamp technology today?
(a) Incandescent
(b) Fluorescent compact
(c) LED
(d) Don't know

27. What does "energy efficiency" mean?

(a) Making responsible use of energy, consuming less energy in each product or service we use, without changing our lifestyle or giving up our comfort

(b) Use minimal energy regardless of what this situation changes in our daily lives

(c) Replace lamps and other equipment

(d) Don't know

28. The single fastest and most cost-effective way to address our energy needs is to
(a) Promote the use of fossil fuels
(b) Stop using fossil fuels
(c) Promote energy conservation
(d) Don't know

29. Which of the following energy-related activities is least harmful to human health and the environment?
(a) Generating electricity with photovoltaic (solar) cells
(b) Generating electricity in a combined cycle plant
(c) Generating electricity in a hydroelectric dam
(d) Don't know

30. The Earth's average temperature is increasing. They say that one important cause of this change is ...
(a) The increasing size of the ozone hole
(b) The increase in carbon dioxide concentrations resulting from the combustion of fossil fuels
(c) Increased incidence of respiratory diseases
(d) Don't know

31. Select the choice that makes the following statement true: Renewable energy resources like wind and solar are still harmful to human health and the environment because 
(a) Wind turbines and photovoltaic (solar) cells have a very short service life

(b) Wind turbines and photovoltaic (solar) cells materials release environmentally harmful substances

(c) It takes a lot of energy and material to manufacture wind turbines and photovoltaic (solar) cells

(d) Don't know

32. How much do you think 1 kilowatt-hour $(\mathrm{kWh})$ of electricity currently costs in Portugal (on average)?

Please indicate your best guess without checking your bill or other resources.

Amount in euros

\section{Don't know}

33. Suppose you saved $100 €$ by purchasing A +++ efficiency appliances. With this money, you invested all of the money in a savings account, whose interest rate is $2 \%$ per year. How much would you have in the account after 5 years if you don't move the money?
(a) More than $102 €$
(b) Exactly $102 €$
(c) Less than $102 €$
(d) Do not know

34. Suppose that the interest rate on your free savings account was $1 \%$ per year and inflation was $2 \%$ per year. After 1 year, with the money in this account, would you be able to buy
(a) More than today
(b) Exactly the same as today
(c) Less than today
(d) Do not know

35. The following statement is true or false? "Buying shares of one single energy company generally provides a safer return than a mutual fund of shares of the energy sector."
(a) True
(b) False
(c) Do not know

36. Imagine a hot water system A which costs $1500 €$ and whose annual electricity expense is $400 €$ and a hot water system B which has a price of $3500 €$ and whose annual electricity expense is $200 €$. How long will it take to recover the difference in the starting price of the two systems, considering the savings in annual electricity expenditure? Assume an interest rate of $0 \%$ for this question.
(a) 1-5 years
(b) 6-10 years
(c) 11-15 years
(d) Do not know

37. Rate each of the following statements according to your degree of agreement with them. 


\begin{tabular}{|c|c|c|c|c|c|}
\hline & Strongly Disagree & Disagree & Neither Agree Nor Disagree & Agree & Strongly Agree \\
\hline \multicolumn{6}{|l|}{$\begin{array}{l}\text { Energy education should be an } \\
\text { important part of the } \\
\text { school curriculum. }\end{array}$} \\
\hline \multicolumn{6}{|l|}{$\begin{array}{l}\text { I would do more to save energy if I } \\
\text { knew how. }\end{array}$} \\
\hline \multicolumn{6}{|l|}{ Saving energy is important. } \\
\hline \multicolumn{6}{|l|}{$\begin{array}{l}\text { All electrical appliances should have } \\
\text { a label that shows the resources used } \\
\text { in making them, their energy } \\
\text { requirements and operating costs. }\end{array}$} \\
\hline \multicolumn{6}{|l|}{$\begin{array}{l}\text { The government should have strict } \\
\text { restrictions on the gas mileage of } \\
\text { new cars. }\end{array}$} \\
\hline \multicolumn{6}{|l|}{$\begin{array}{l}\text { We should make more of our } \\
\text { electricity from renewable sources. }\end{array}$} \\
\hline \multicolumn{6}{|l|}{$\begin{array}{l}\text { Portugal should develop more ways } \\
\text { to use renewable energy, even if it } \\
\text { means that energy will cost more. }\end{array}$} \\
\hline \multicolumn{6}{|l|}{$\begin{array}{l}\text { Portuguese people should save } \\
\text { more energy. }\end{array}$} \\
\hline \multicolumn{6}{|l|}{$\begin{array}{l}\text { Efforts to develop renewable energy } \\
\text { technologies are more important than } \\
\text { efforts to develop new sources of } \\
\text { fossil fuels. }\end{array}$} \\
\hline $\begin{array}{l}\text { More wind farms should be built to } \\
\text { generate electricity, even if the wind } \\
\text { farms are located in scenic valleys, } \\
\text { farmlands, and wildlife areas. }\end{array}$ & & & & & \\
\hline
\end{tabular}

More oil fields should be developed

as they are discovered, even if they

are located in areas protected by

environmental laws.

If there were promotional and

educational activities related to

energy conservation, I would

participate.

The way I personally use energy does

not really make a difference to the

energy problems that face our nation.

I believe that I can contribute to

solving energy problems by making

appropriate energy-related choices

and actions.

I believe that I can contribute to

solving energy problems by working

with others.

I don't have to worry about turning

lights or computers off in the

classroom, because the university

pays for the electricity.

If there were compensation for energy

conservation activities, I would be

willing to participate in them

more actively.

38. Rate each of the following statements according to how often you perform the actions reported. 


\begin{tabular}{|c|c|c|c|c|c|}
\hline & Never & Not very Often & Sometimes & Almost Always & Always \\
\hline \multicolumn{6}{|l|}{ I try to save water. } \\
\hline \multicolumn{6}{|l|}{$\begin{array}{l}\text { I walk or bike to go short distances, instead } \\
\text { of asking for a ride in the car. }\end{array}$} \\
\hline \multicolumn{6}{|l|}{ When I leave a room, I turn off the lights. } \\
\hline \multicolumn{6}{|l|}{$\begin{array}{l}\text { Many of my everyday decisions are } \\
\text { affected by my thoughts on energy use. }\end{array}$} \\
\hline \multicolumn{6}{|l|}{$\begin{array}{l}\text { I or my family turn the heat down at night } \\
\text { to save energy. }\end{array}$} \\
\hline \multicolumn{6}{|l|}{$\begin{array}{l}\text { I or my family buy energy compact } \\
\text { fluorescent light bulbs. }\end{array}$} \\
\hline \multicolumn{6}{|l|}{$\begin{array}{l}\text { I am willing to buy some things to } \\
\text { save energy. }\end{array}$} \\
\hline \multicolumn{6}{|l|}{$\begin{array}{l}\text { I use rechargeable batteries in the } \\
\text { equipment if it allows. }\end{array}$} \\
\hline \multicolumn{6}{|l|}{$\begin{array}{l}\text { I close the curtains/blinds during } \\
\text { the summer. }\end{array}$} \\
\hline \multicolumn{6}{|l|}{$\begin{array}{l}\text { I leave the windows open when the heating } \\
\text { is on. }\end{array}$} \\
\hline I do not leave the equipment on standby. & & & & & \\
\hline
\end{tabular}

Thank you very much for your collaboration!

\section{Appendix B}

Table A1. Stepwise estimations considering energy knowledge as the dependent variable.

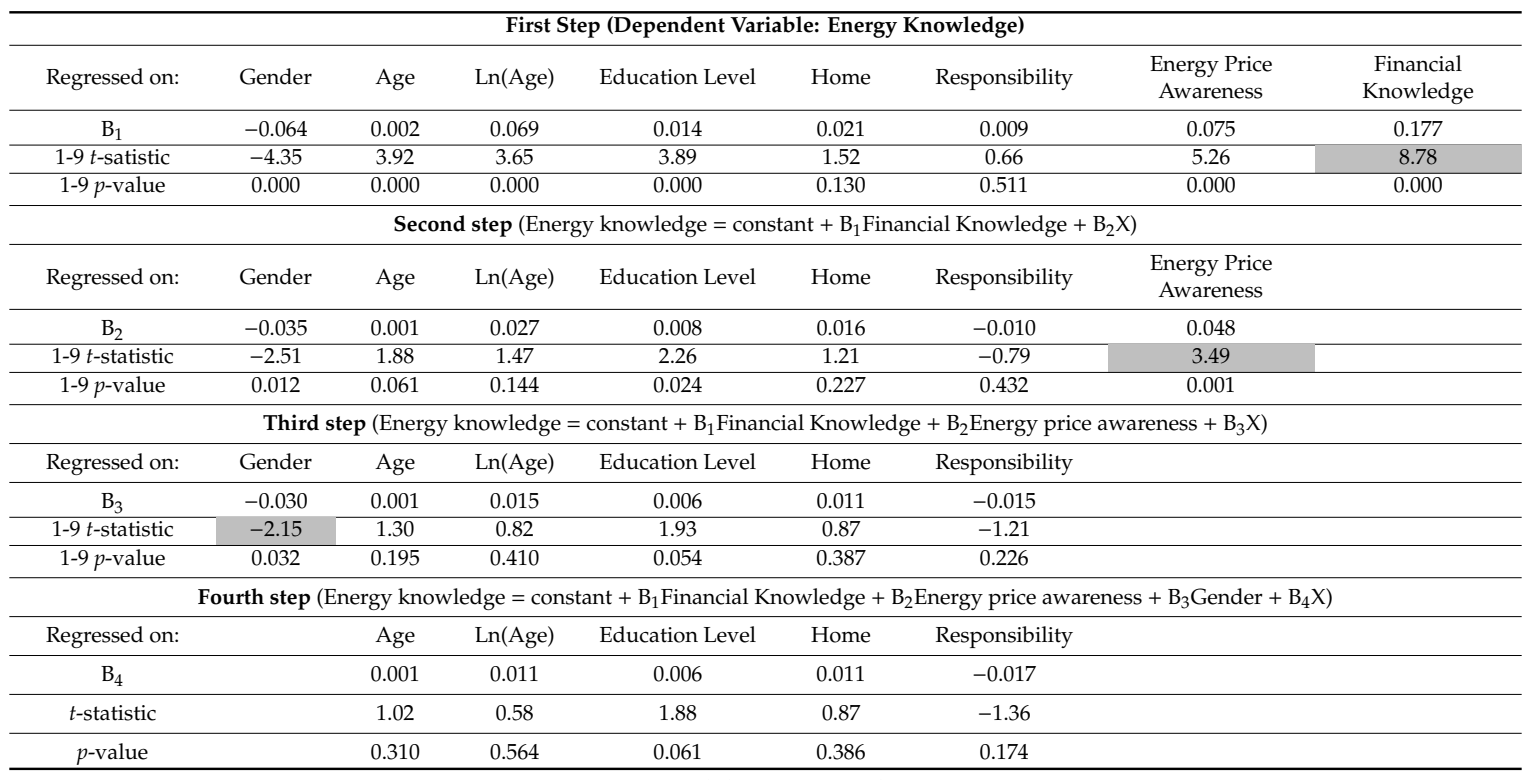

Source: Own elaboration with Stata 16. 
Table A2. Stepwise estimations considering attitude as the dependent variable.

\begin{tabular}{|c|c|c|c|c|c|c|c|c|c|}
\hline \multicolumn{10}{|c|}{ First Step (Dependent Variable: Attitude) } \\
\hline Regressed on: & Gender & Age & Ln(Age) & $\begin{array}{l}\text { Education } \\
\text { Level }\end{array}$ & Home & Responsibility & $\begin{array}{l}\text { Energy Price } \\
\text { Awareness }\end{array}$ & $\begin{array}{c}\text { Financial } \\
\text { Knowledge }\end{array}$ & $\begin{array}{c}\text { Energy } \\
\text { Knowledge }\end{array}$ \\
\hline $\mathrm{B}_{1}$ & 0.019 & 0.000 & 0.005 & 0.003 & 0.004 & 0.004 & 0.015 & 0.023 & 0.094 \\
\hline 1-10t-satistic & 2.50 & 0.40 & 0.46 & 1.46 & 0.52 & 0.49 & 1.95 & 1.99 & 3.67 \\
\hline $1-10 p$-value & 0.013 & 0.689 & 0.647 & 0.144 & 0.604 & 0.626 & 0.052 & 0.047 & 0.000 \\
\hline \multicolumn{10}{|c|}{ Second step $\left(\right.$ Attitude $=$ constant $+B_{1}$ Energy Knowledge $\left.+B_{2} X\right)$} \\
\hline Regressed on: & Gender & Age & Ln(Age) & $\begin{array}{c}\text { Education } \\
\text { Level }\end{array}$ & Home & Responsibility & $\begin{array}{l}\text { Energy Price } \\
\text { Awareness }\end{array}$ & $\begin{array}{l}\text { Financial } \\
\text { Knowledge }\end{array}$ & \\
\hline $\mathrm{B}_{2}$ & 0.026 & -0.000 & -0.002 & 0.001 & 0.002 & 0.003 & 0.009 & 0.007 & \\
\hline $1-10 t$-statistic & 3.41 & -0.30 & -0.19 & 0.80 & 0.25 & 0.38 & 1.08 & 0.60 & \\
\hline $1-10 p$-value & 0.001 & 0.766 & 0.848 & 0.423 & 0.800 & 0.707 & 0.281 & 0.551 & \\
\hline \multicolumn{10}{|c|}{ Third step (Attitude $=$ constant $+B_{1}$ Energy Knowledge $+B_{2}$ Gender $\left.+B_{3} X\right)$} \\
\hline Regressed on: & & Age & Ln(Age) & $\begin{array}{l}\text { Education } \\
\text { Level }\end{array}$ & Home & Responsibility & $\begin{array}{l}\text { Energy Price } \\
\text { Awareness }\end{array}$ & $\begin{array}{l}\text { Financial } \\
\text { Knowledge }\end{array}$ & \\
\hline $\mathrm{B}_{3}$ & & 0.000 & 0.004 & 0.002 & 0.002 & 0.005 & 0.012 & 0.016 & \\
\hline$t$-statistic & & 0.32 & 0.39 & 1.01 & 0.29 & 0.77 & 1.54 & 1.27 & \\
\hline$p$-value & & 0.747 & 0.697 & 0.313 & 0.772 & 0.440 & 0.124 & 0.204 & \\
\hline
\end{tabular}

Source: Own elaboration with Stata 16.

Table A3. Stepwise estimations considering behavior as a dependent variable.

\begin{tabular}{|c|c|c|c|c|c|c|c|c|c|c|}
\hline \multicolumn{11}{|c|}{ First Step (Dependent Variable: Behavior) } \\
\hline Regressed on: & Gender & Age & Ln(Age) & $\begin{array}{c}\text { Education } \\
\text { Level }\end{array}$ & Home & Responsibility & $\begin{array}{l}\text { Energy Price } \\
\text { Awareness }\end{array}$ & $\begin{array}{l}\text { Financial } \\
\text { Knowledge }\end{array}$ & $\begin{array}{c}\text { Energy } \\
\text { knowledge }\end{array}$ & Attitude \\
\hline $\mathrm{B}_{1}$ & 0.020 & -0.000 & -0.003 & -0.001 & 0.007 & -0.005 & 0.021 & 0.028 & 0.116 & 0.520 \\
\hline 1-11 $t$-satistic & 2.25 & -0.39 & -0.23 & -0.62 & 0.87 & -0.59 & 2.37 & 2.10 & 3.91 & 10.08 \\
\hline 1-11 $p$-value & 0.025 & 0.699 & 0.820 & 0.537 & 0.386 & 0.556 & 0.018 & 0.037 & 0.000 & 0.000 \\
\hline \multicolumn{11}{|c|}{ Second step $\left(\right.$ Behavior $=$ constant $+B_{1}$ Attitude $\left.+B_{2} X\right)$} \\
\hline Regressed on: & Gender & Age & Ln(Age) & $\begin{array}{c}\text { Education } \\
\text { Level }\end{array}$ & Home & Responsibility & $\begin{array}{l}\text { Energy Price } \\
\text { Awareness }\end{array}$ & $\begin{array}{l}\text { Financial } \\
\text { Knowledge }\end{array}$ & $\begin{array}{c}\text { Energy } \\
\text { knowledge }\end{array}$ & \\
\hline $\mathrm{B}_{2}$ & 0.010 & -0.000 & -0.005 & -0.003 & 0.005 & -0.007 & 0.014 & 0.016 & 0.069 & \\
\hline 1-11 $t$-statistic & 1.28 & -0.63 & -0.48 & -1.42 & 0.71 & -0.90 & 1.67 & 1.35 & 2.55 & \\
\hline $1-11 p$-value & 0.203 & 0.528 & 0.630 & 0.155 & 0.479 & 0.368 & 0.095 & 0.178 & 0.011 & \\
\hline \multicolumn{11}{|c|}{ Third step $\left(\right.$ Behavior $=$ constant $+B_{1}$ Attitude $+B_{2}$ Energy Knowledge $\left.+B_{3} X\right)$} \\
\hline Regressed on: & Gender & Age & Ln(Age) & $\begin{array}{c}\text { Education } \\
\text { Level }\end{array}$ & Home & Responsibility & $\begin{array}{l}\text { Energy Price } \\
\text { Awareness }\end{array}$ & $\begin{array}{l}\text { Financial } \\
\text { Knowledge }\end{array}$ & & \\
\hline $\mathrm{B}_{3}$ & 0.016 & -0.000 & -0.010 & -0.003 & 0.004 & -0.007 & 0.009 & 0.005 & & \\
\hline$t$-statistic & 1.95 & -1.14 & -0.95 & -1.93 & 0.53 & -0.98 & 1.10 & 0.40 & & \\
\hline$p$-value & 0.051 & 0.254 & 0.342 & 0.055 & 0.594 & 0.327 & 0.271 & 0.693 & & \\
\hline
\end{tabular}

Source: Own elaboration with Stata 16.

\section{References}

1. Blasch, J.; Boogen, N.; Filippini, M.; Kumar, N. Explaining electricity demand and the role of energy and investment literacy on end-use efficiency of Swiss households. Energy Econ. 2017, 68, 89-102. [CrossRef]

2. U.S. Department of Energy. Energy Literacy: Essencial Principles and Fundamental Concepts for Energy Education; U.S. Department of Energy: Washignton, DC, USA, 2017.

3. Dewaters, J.; Qaqish, B.; Graham, M.; Powers, S. Designing an Energy Literacy Questionnaire for Middle and High School Youth. J. Environ. Educ. 2013, 44, 56-78. [CrossRef]

4. Martins, A.; Madaleno, M.; Dias, M.F. Energy literacy: What is out there to know? Energy Rep. 2020, 6, 454-459. [CrossRef]

5. Dewaters, J.; Powers, S.E. Energy literacy of secondary students in New York State (USA): A measure of knowledge, affect, and behavior. Energy Policy 2011, 39, 1699-1710. [CrossRef]

6. Bodzin, A. Investigating Urban Eighth-Grade Students' Knowledge of Energy Resources. Int. J. Sci. Educ. 2012, 34, 1255-1275. [CrossRef]

7. Sovacool, B.K.; Blyth, P.L. Energy and environmental attitudes in the green state of Denmark: Implications for energy democracy, low carbon transitions, and energy literacy. Environ. Sci. Policy 2015, 54, 304-315. [CrossRef]

8. Chen, S.-J.; Chou, Y.-C.; Yen, H.-Y.; Chao, Y.-L. Investigating and structural modeling energy literacy of high school students in Taiwan. Energy Effic. 2015, 8, 791-808. [CrossRef] 
9. Lee, L.-S.; Lee, Y.-F.; Altschuld, J.W.; Pan, Y.-J. Energy literacy: Evaluating knowledge, affect, and behavior of students in Taiwan. Energy Policy 2015, 76, 98-106. [CrossRef]

10. Aguirre-Bielschowsky, I.; Lawson, R.; Stephenson, J.; Todd, S. Energy literacy and agency of New Zealand children. Environ. Educ. Res. 2015, 23, 832-854. [CrossRef]

11. Cotton, D.; Shiel, C.; Paço, A. Energy saving on campus: A comparison of students' attitudes and reported behaviours in the UK and Portugal. J. Clean. Prod. 2016, 129, 586-595. [CrossRef]

12. Paço, A.; Alves, H.; Shiel, C.; Filho, W.L. Conserving Behaviour: A Replication of the ENVIROCON Scale in Four Countries. APCBEE Procedia 2013, 5, 44-49. [CrossRef]

13. Blasch, J.; Boogen, N.; Daminato, C.; Filippini, M. Empower the Consumer! Energy-Related Financial Literacy and its Socioeconomic Determinants. SSRN Electron. J. 2018. [CrossRef]

14. Kalmi, P.; Trotta, G.; Kazukauskas, A. The Role of Energy Literacy as a Component of Financial Literacy: Survey-Based Evidence from Finland. In Proceedings of the 15th IAEE European Conference, Vienna, Austria, 3-6 September 2017.

15. Danner, U.N.; Aarts, H.; Vries, N.K. Habit vs. intention in the prediction of future behaviour: The role of frequency, context stability and mental accessibility of past behaviour. Br. J. Soc. Psychol. 2008, 47, 245-265. [CrossRef] [PubMed]

16. Maréchal, K. Not irrational but habitual: The importance of "behavioural lock-in" in energy consumption. Ecol. Econ. 2010, 69, 1104-1114. [CrossRef]

17. Kumar, N. A Descriptive Overview of Literacy, Attitudes and Behaviours towards Energy Consumption in Nepal; Centre for Energy Policy and Economics (CEPE), ETH Zürich: Zurich, Switzerland, 2018.

18. Filippini, M.; Kumar, N.; Srinivasan, S. Energy-Related Financial Literacy and Bounded Rationality in Appliance Replacement Attitudes: Evidence from Nepal; Economics Working Paper Series 19/315; CER-ETH—Center of Economic Research: Zurich, Switzerland, 2019.

19. Filippini, M.; Blasch, J.; Boogen, N.; Kumar, N. Energy Efficiency, Bounded Rationality and Energy-Related Financial Literacy in the Swiss Household Sector; ETH Zurich: Zurich, Switzerland, 2018.

20. Cotton, D.; Winter, J.; Miller, W.; Valle, L.D. Is students' energy literacy related to their university's position in a sustainability ranking? Environ. Educ. Res. 2017, 24, 1611-1626. [CrossRef]

21. Räty, R.; Carlsson-Kanyama, A. Energy consumption by gender in some European countries. Energy Policy 2010, 38, 646-649. [CrossRef]

22. Ballantyne, R.; Connell, S.; Fien, J. Students as catalysts of environmental change: A framework for researching intergenerational influence through environmental education. Environ. Educ. Res. 2006, 12, 413-427. [CrossRef]

23. Toth, N.; Little, L.; Read, J.; Fitton, D.; Horton, M. Understanding teen attitudes towards energy consumption. J. Environ. Psychol. 2013, 34, 36-44. [CrossRef]

24. Broek, K.L.V.D.; Walker, I. Exploring the perceptions of drivers of energy behaviour. Energy Policy 2019, 129, 1297-1305. [CrossRef]

25. Lee, L.-S.; Chang, L.-T.; Lai, C.-C.; Guu, Y.-H.; Lin, K.-Y. Energy literacy of vocational students in Taiwan. Environ. Educ. Res. 2015, 23, 1-19. [CrossRef]

26. Boogen, N. Empirical Estimation of the Level of Energy Efficiency in the European Household Sector: Evidence from Italy, the Netherlands and Switzerland. In Proceedings of the 41st IAEE International Conference-“"Transforming Energy Markets", Groningen, Netherlands, 10-13 June 2018.

27. Kumar, N. A Model-based Clustering Approach for Analyzing Energy-related Financial Literacy and Its Determinants. SSRN Electron. J. 2019. [CrossRef]

28. Brutscher, P. Payment Matters? - An Exploratory Study into the Pre-Payment Electricity Metering; Cambridge Working Paper in Economics, 1108; University of Cambridge: Cambridge, UK, 2011.

29. Dianshu, F.; Sovacool, B.K.; Vu, K. The barriers to energy efficiency in China: Assessing household electricity savings and consumer behavior in Liaoning Province. Energy Policy 2010, 38, 1202-1209. [CrossRef]

30. Heutel, G. Prospect theory and energy efficiency. J. Environ. Econ. Manag. 2019, 96, 236-254. [CrossRef]

31. Blasch, J.; Kumar, N.; Filippini, M. Boundedly rational consumers, energy and investment literacy, and the display of information on household appliances. Resour. Energy Econ. 2016, 56, 39-58. [CrossRef]

32. Gaies, B.; Kaabia, O.; Ayadi, R.; Guesmi, K.; Abid, I. Financial development and energy consumption: Is the MENA region different? Energy Policy 2019, 135, 111000. [CrossRef] 
33. DeWaters, J.E.; Powers, S.E.; Graham, M. Developing an energy literacy scale. In Proceedings of the 114th Annu. ASEE Conf. Expo., Honolulu, HI, USA, 23-28 June 2007.

34. Brounen, D.; Kok, N.; Quigley, J.M. Energy literacy, awareness, and conservation behavior of residential households. Energy Econ. 2013, 38, 42-50. [CrossRef]

35. Na Kang, N.; Cho, S.H.; Han, H. The energy-saving effects of apartment residents' awareness and behavior. Energy Build. 2012, 46, 112-122. [CrossRef]

36. Zografakis, N.; Menegaki, A.; Tsagarakis, K.P. Effective education for energy efficiency. Energy Policy 2008, 36, 3226-3232. [CrossRef]

37. Blasch, J.; Boogen, N.; Filippini, M.; Kumar, N. The Role of Energy and Investment Literacy for Residential Electricity Demand and End-use Efficiency. SSRN Electron. J. 2017. [CrossRef]

38. Lusardi, A.; Mitchell, O.S. The Economic Importance of Financial Literacy: Theory and Evidence. J. Econ. Lit. 2014, 52, 5-44. [CrossRef]

39. Energia, S. Quiz Energia. 2019. Available online: http://www.senergia.pt/quizzes/quiz-energia/ (accessed on 29 June 2019).

40. Barrow, L.H.; Morrisey, J.T. Ninth-Grade Students' Attitudes toward Energy: A Comparison between Maine and New Brunswick. J. Environ. Educ. 1987, 18, 15-21. [CrossRef]

41. Armstrong, J.B.; Impara, J.C. The Impact of an Environmental Education Program on Knowledge and Attitude. J. Environ. Educ. 1991, 22, 36-40. [CrossRef]

42. Cotton, D.; Miller, W.; Winter, J.; Bailey, I.; Sterling, S. Developing students' energy literacy in higher education. Int. J. Sustain. High. Educ. 2015, 16, 456-473. [CrossRef]

(C) 2020 by the authors. Licensee MDPI, Basel, Switzerland. This article is an open access article distributed under the terms and conditions of the Creative Commons Attribution (CC BY) license (http://creativecommons.org/licenses/by/4.0/). 